\title{
Soil microbial and chemical properties influenced by continuous cropping
}

\section{of banana}

\author{
Jianbo Sun, Liangping Zou, Wenbin Li, Yuguang Wang, Qiyu Xia, Ming Peng*
}

Ministry of Agriculture/Institute of Tropical Bioscience and Biotechnology - Chinese Academy of Tropical Agricultural Sciences - Key Lab. of Biology and Genetic Resources of Tropical Crops, 4 Xue yuan Road - 571101 - Haikou China.

*Corresponding author <sunjb126@126.com>

Edited by: Fernando Dini Andreote

Received December 30, 2016

Accepted June 06, 2017

\begin{abstract}
The impacts of continuous cropping of banana on soil microbiological and biochemical properties are little understood. In this study, we evaluated the variations in soil bacterial community abundance and diversity, microbial biomass carbon (MBC) and nitrogen (MBN) as well as soil enzyme activities involved in $\mathrm{C}, \mathrm{N}$ and $\mathrm{P}$ cycles as affected by continuous cropping of banana. An initial increase in bacterial 16S rRNA copy and soil microbial biomass was observed in the second cropping and then decreased until the fourth cropping. The diversity of bacterial community showed a continuous decrease throughout the experiment. In addition, continuous cropping of banana caused shifts in bacterial community composition and structures. Soil urease and invertase exhibited the highest activities in the second cropping and then decreased gradually from the second to the fourth cropping. The phosphatase activity showed a gradual increase from the first to the third cropping. The bacterial 16S rRNA copy was positively correlated with the contents of MBN and urease activities. The results indicated that continuous cropping of banana was responsible for the disturbance of the bacterial community and that the effect on enzyme activity varies depending on the type of soil enzyme.
\end{abstract}

Keywords: rhizosphere, soil bacterial abundance, bacterial community diversity, soil microbial biomass, soil enzymes

\section{Introduction}

Banana is one of the most important food crops in tropical and subtropical regions. However, continuous cropping results in serious occurrence of Fusarium wilt of banana, leading to the reduction of banana production and quality indirectly. The mechanism of continuous cropping obstacles is very complex. The disturbance of soil microbial ecosystem is believed to play an important role in the processes (Zhou and $\mathrm{Wu}, 2012$ ). Soil microorganisms are involved in many important soil biological processes, such as nutrient mineralization and cycling, soil organic matter transformation and residue decomposition. These biochemical processes carried out by soil microorganisms is critical to the maintenance of soil quality and sustainability, and, consequently, disease susceptibility of the crop (Senechkin et al., 2014; van Bruggen et al., 2015).

Soil microorganisms and soil enzymes play critical roles in the functional processes in soil ecosystems. Soil management practices have a direct effect on soil microbial communities and enzymes. A previous study has documented the effects of continuous cropping on soil microbial communities and enzyme activities (GilSotres et al., 2005). A reduction in diversity of microbial communities was observed in continuous cucumber cro pping soils as compared with rotation (Zhou et al., 2014). Decreases in soil hydrolase activities were also reported in continuous-pea (Nayyar et al., 2009).

Many factors can affect soil microbial communities under continuous cropping, including soil characteristics and environmental conditions. Currently, little is known about the effects of continuous cropping of banana on soil microbial and enzyme characteristics on tropical sandy soils, and how the microbial communities influences the soil enzyme activities.

The objectives of the current work were to evaluate the effects of continuous cropping of banana on rhizosphere microbial communities and enzyme activities. Additionally, correlations among soil microbial communities and enzyme activities were determined.

\section{Materials and Methods}

\section{Experimental design and soil sampling}

The study was conducted in a plastic greenhouse in Haikou $\left(20^{\circ} 05^{\prime} \mathrm{N}, 110^{\circ} 10^{\prime} \mathrm{E}\right.$, with an altitude of 21 $\mathrm{m}$ above sea level), China. The soil is tropical red loam with about $672 \mathrm{~g} \mathrm{~kg}^{-1}$ sand and $80 \mathrm{~g} \mathrm{~kg}^{-1}$ clay. It contained $12.74 \mathrm{~g} \mathrm{~kg}^{-1}$ organic matter, $98.18 \mathrm{mg} \mathrm{kg}^{-1}$ available $\mathrm{N}, 13.35 \mathrm{mg} \mathrm{kg}^{-1}$ available $\mathrm{P}, 65.50 \mathrm{mg} \mathrm{kg}^{-1}$ available $\mathrm{K}$, and with a pH 5.93. The experiment was carried out in a randomized block design with three replications. The plantlets of banana with 6 leaves were transplanted into a pot $(31 \mathrm{~cm}$ height $\times 38 \mathrm{~cm}$ diameter $)$ placed in greenhouse, with 1 plantlet per pot. The pots were filled with the red loam soil. Each pot was fertilized with the compound fertilizer $\left(15 \% \mathrm{~N}, 15 \% \mathrm{P}_{2} \mathrm{O}_{5}, 15 \% \mathrm{~K}_{2} \mathrm{O}\right)$, fertilization and irrigation were performed once a week. The soil moisture content was kept at about $60-70 \%$ of field water-holding capacity.

The experiment was initiated in Feb 2013. A continuous cropping of banana was set up. Four treatments were: (1) the first cropping (July-Nov 2014), (2) the second cropping (Jan-June 2014; July-Nov 2014), (3) the third cropping (Aug-Dec 2013; Jan-June 2014; July-Nov 
2014), and (4) the fourth cropping (Feb-July 2013; AugDec 2013; Jan-June 2014; July-Nov 2014). After each continuous cropping, root pieces in the soil were picked out and new plantlets were transplanted into the pots. Pots without planting of banana were served as controls in each treatment. Other managements were the same as the treatments of the continuous cropping.

The soil adhering tightly to the roots was collected as rhizosphere soil. Each soil samples was collected from three bananas and then mixed as one replicate. The soil samples were sieved ( $2 \mathrm{~mm}$ mesh) and then stored at 4 ${ }^{\circ} \mathrm{C}$ until analysis.

\section{Soil DNA extraction and real-time PCR}

The total DNA from a $0.5 \mathrm{~g}$ soil sample was extracted using a Fast DNA SPIN kit for soil (Qbiogene) according to the manufacturer's protocol. Three DNA extractions from each soil sample were performed and then pooled for analysis. The quantity and concentration of the DNA extractions were checked with a spectrophotometer (Jasco).

Bacteria abundances were evaluated semi-quantitatively by the $16 \mathrm{~S}$ rRNA gene copy numbers. The realtime PCR was performed using an MX3000PTM QPCR system (Stratagene). Amplification was carried out in 25 $\mu \mathrm{L}$ reaction volumes containing $12.5 \mu \mathrm{L}$ of SYBR Green PCR Master Mix, $10 \mathrm{ng}$ of diluted template DNA, 0.1 $\mu \mathrm{M}$ of each primer: 338f (5'-CCTACGGGAGGCAGCAG $\left.-3^{\prime}\right)$ and 518r (5'-ATTACCGCGGCTGCTGG -3') for each qPCR amplification (Seghers et al., 2003). The qPCR conditions were as follows: $95^{\circ} \mathrm{C}$ for $3 \mathrm{~min}$, followed by 40 cycles of $95{ }^{\circ} \mathrm{C}$ for $30 \mathrm{~s}, 53^{\circ} \mathrm{C}$ for $40 \mathrm{~s}$, and $72^{\circ} \mathrm{C}$ for $1 \mathrm{~min}$. All amplifications were performed in triplicate.

The bacterial 16S rRNA gene was amplified with the $27 \mathrm{f}\left(5^{\prime}\right.$-AGAGTTTGATCCTGGCTCAG -3') and 1492r primers (5'-GGTTACCTTGTTACGACTT -3') (Ahn et al., 2009) and then cloned into the pGEM -T Easy Vector (Promega). The plasmids were extracted and used as standards for the calibration curves, which were generated by serial plasmid DNA dilutions. The copy number of each solution had been determined previously.

\section{Terminal restriction fragment length} polymorphism (T-RFLP) analysis

T-RFLP was used to analyze the soil bacterial community structures. The bacterial $16 \mathrm{~S}$ rRNA genes were amplified using the 27f (5'-AGAGTTTGATCCTGGCTCAG-3') and 1492r (5'-GGTTACCTTGTTACGACTT-3') primers (Ahn et al., 2009). The $27 \mathrm{f}$ primer was labeled with 6-carboxyfluorescein (6-FAM) at the 5' end. The reaction mixtures had a final volume of $50 \mu \mathrm{L}$ and contained $20 \mathrm{ng}$ of template DNA, $1 \times$ PCR reaction buffer, $0.1 \mu \mathrm{M}$ of each primer, $2.0 \mathrm{mM} \mathrm{MgCl}, 200 \mu \mathrm{M}$ dNTP mixture, and $2.5 \mathrm{U}$ of Taq DNA polymerase (Sangon). The PCR conditions were as follows: initial denaturation at $95{ }^{\circ} \mathrm{C}$ for $5 \mathrm{~min}, 30$ cycles with denaturation (1 min at $\left.94^{\circ} \mathrm{C}\right)$; annealing $\left(1 \mathrm{~min}\right.$ at $\left.52^{\circ} \mathrm{C}\right)$; and elongation $(1.5$ $\min$ at $72^{\circ} \mathrm{C}$ ), with a final extension of $7 \mathrm{~min}$ at $72^{\circ} \mathrm{C}$.
The PCR products were purified using a Qiagen gel extraction kit (Qiagen). Approximately $200 \mathrm{ng}$ of purified products were digested using the HaeIII restriction enzyme (MBI) at $37^{\circ} \mathrm{C}$ for $3 \mathrm{~h}$ (Hemkemeyer et al., 2015). The digestion volume was $30 \mu \mathrm{L}$ and contained $10 \mu \mathrm{L}$ of PCR product, $3.0 \mu \mathrm{L}$ of $10 \times$ buffer and $3 \mathrm{U}$ of HaeIII. The digestion products were purified using a gel extraction kit (Omega). The three replicates of the purified products were mixed. The terminal restriction fragment (TRF) size was determined by an ABI 373 sequencer (Applied Biosystems). The TRFs profiles were analyzed using GeneMapper software 4.0 (Applied Biosystem). Only TRFs between $50 \mathrm{bp}$ and $600 \mathrm{bp}$ and with peak heights over a threshold of 50 fluorescence units were considered for further analysis.

\section{Soil microbial biomass}

Soil microbial biomass carbon $(\mathrm{MBC})$ and microbial biomass nitrogen (MBN) were determined by the fumigation extraction method (Vance et al., 1987). Soil samples (equivalent to $20 \mathrm{~g}$ dry weight) were incubated at $60 \%$ of water holding capacity for 7 days, and then fumigated with ethanol-free chloroform for $24 \mathrm{~h}$. After fumigant removal, the soil was extracted with $80 \mathrm{~mL} 0.5$ $\mathrm{M} \mathrm{K}_{2} \mathrm{SO}_{4}$ for $30 \mathrm{~min}$ on a rotating shaker and then the extract was filtered. The non-fumigated soils were extracted in the same way. Total dissolved organic C (DOC) and total dissolved organic $\mathrm{N}$ (DON) in the extracts were determined using a total organic $\mathrm{C}$ analyzer (Multi N/C 3100).

Soil microbial biomass was calculated as follows: $\mathrm{MBC}=\mathrm{EC} / \mathrm{KEC}$, and $\mathrm{MBN}=\mathrm{EN} / \mathrm{KEN}$, respectively. The EC (extracted organic C) and the EN (extracted organic $\mathrm{N}$ ) were the difference between the fumigated values and the non-fumigated values of DOC and DON, respectively. The correction factor of $\mathrm{KEC}=0.45$, and the $\mathrm{KEN}=0.54$, respectively (Joergensen and Potthoff, 2005).

\section{Soil enzyme activities}

Urease activity was determined according to Kizilkaya et al. (2004). A 5 g air-dried soil sample was mixed with $10 \mathrm{~mL}$ of citrate buffer (pH 6.7), $1 \mathrm{~mL}$ of methylbenzene and $10 \mathrm{~mL}$ of $10 \%$ urea substrate solution. The mixture was incubated for $24 \mathrm{~h}$ at $37^{\circ} \mathrm{C}$. After incubation and filtration, $1 \mathrm{~mL}$ of filtrate was diluted to $10 \mathrm{~mL}$ and then added to $4 \mathrm{~mL}$ of $13 \%$ sodium phenolate and $3 \mathrm{~mL}$ of $1 \%$ sodium hypochloride. The released ammonium was analyzed at $578 \mathrm{~nm}$. To determine the invertase activity, $5 \mathrm{~g}$ air-dried soil was mixed with 5 $\mathrm{mL}$ phosphate buffer, $15 \mathrm{~mL}$ of $8 \%$ sucrose solution and $1 \mathrm{~mL}$ of methylbenzene, and then incubating the solution for $24 \mathrm{~h}$ at $37^{\circ} \mathrm{C}$. The filtrate was reacted with 3,5-dinitrosalicylic acid and the invertase activity was determined at $508 \mathrm{~nm}$ (Wang et al., 2009). The phosphatase activity was determined by incubating $5 \mathrm{~g}$ of air-dried soil with $20 \mathrm{~mL}$ of disodium phenyl phosphate and $1 \mathrm{~mL}$ of methylbenzene for $2 \mathrm{~h}$ at $37^{\circ} \mathrm{C}$. Then $5 \mathrm{~mL}$ 
of the filtrated mixture was reacted with $0.5 \mathrm{~mL} \mathrm{4-ami-}$ nophenazone and $0.5 \mathrm{~mL}$ potassium ferricyanide. The phosphatase activity was measured at $510 \mathrm{~nm}$ (Wang et al., 2009).

\section{Statistical analysis}

The Shannon diversity indices $\left(H^{\prime}\right)$ were calculated as follows: $\left(H^{\prime}\right)=-\sum_{i}^{s} p i \ln p i$, where $p i$ is the peak area proportion of the ith TRF out of the total peak area for all TRFs. The $S$ is the total number of TRFs in the profile. The relative abundance of each TRF was calculated by dividing the peak area of the single TRFs by the sum of the total peak area with one sample.

Statistical analyses were performed using the SPSS 11.5 for windows. To evaluate entirely the differences of soil properties between continuous cropping of banana and the control, principal component analyses (PCA) were applied using CANOCO software for Windows 4.5 (Microcomputer Power), and mean values data of soil microbiological and biochemical properties were submitted to PCA analyses. One-way ANOVA was used to evaluate the difference between mean values. When significance was obtained at the $p<0.05$ level, Fisher's Least Significant Difference (LSD) Test was used to evaluate multiple comparisons. Pearson's correlation analysis was carried out to compare the significant correlation between soil microbial and biochemical properties.

\section{Results}

\section{Bacterial 16S rRNA copy in the rhizosphere soil}

The number of $16 \mathrm{~S}$ rRNA gene was initially increased at the second cropping and then decreased gradually until the fourth cropping (Figure 1). In contrast, there was an increase in 16S rRNA gene numbers in the control soil as cropping activities increased. From the first to the second cropping, the numbers of $16 \mathrm{~S}$ rRNA gene were significantly $(p<0.05)$ higher compared to

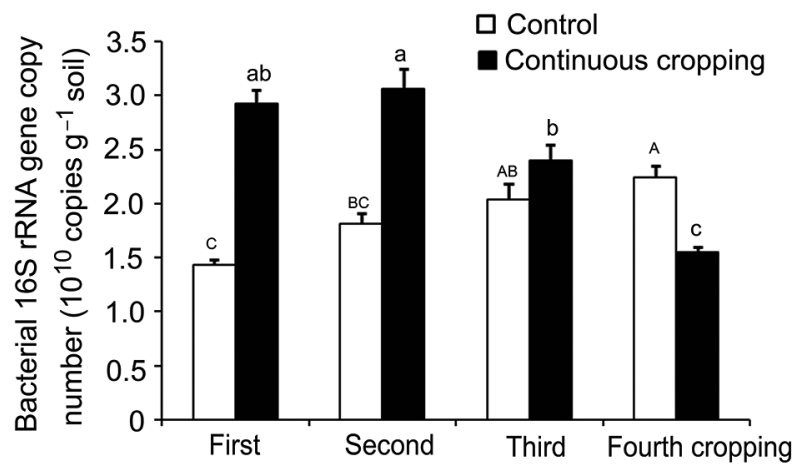

Figure 1 - Quantification of bacterial 16S rRNA gene copy numbers in the rhizosphere soil of the continuous cropping of banana. Means followed by the different letters in the column within the same cropping times are significantly different at $p<0.05$ (LSD test). the control. However, the bacterial 16S rRNA copy was significantly $(p<0.05)$ lower in the fourth cropping than that of the control.

\section{T-RFLP analysis of bacterial community diversity} and composition

When comparing the TRF profiles of the different rhizosphere soil samples, differences in the bacterial composition were observed. Thirteen TRFs were present in all the samples. The numbers of TRFs that were present only in each continuous cropping were different. In the first, second, third and the fourth cropping, the numbers were $13,18,14$ and 11 , respectively.

According to the Shannon index, continuous cropping led to a decreasing tendency in diversity of the rhizosphere soil bacterial communities during the experiment (Figure 2). However, the diversity of bacterial communities tended to increase in the control throughout the cropping. In the first and second cropping, the diversity was significantly higher $(p<0.05)$ in the continuous cropping than that in the control. However, in the third and fourth continuous cropping, there was a significantly $(p<0.05)$ lower diversity of bacterial communities in rhizosphere soil compared to the control.

\section{Soil microbial biomass}

Table 1 shows the variation in microbial biomass with different continuous cropping. The MBC content was higher in the second cropping and then tended to decrease until the fourth cropping. As the cropping activity increased, there was an increasing trend in $\mathrm{MBC}$ in the control. Differences $(p<0.05)$ were detected in $\mathrm{MBC}$ in the first and second cropping compared to the control. The MBN content displayed a similar decreasing trend to $\mathrm{MBC}$ in continuous cropping. There were differences $(p<0.05)$ in MBN between continuous cropping and control with the exception of the fourth cropping.

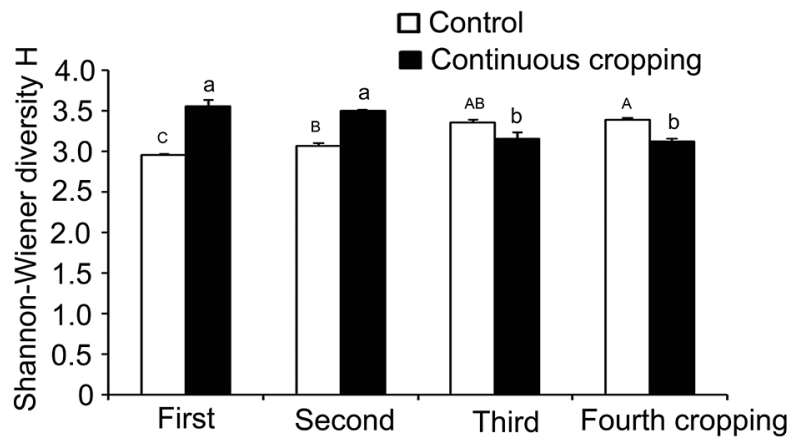

Figure 2 - Shannon diversity indices of the bacterial communities in the rhizosphere soil according to the terminal restriction fragment (TRF) profile; means followed by the different letters in the column within the same cropping times are significantly different at $p<$ 0.05 (LSD test). 


\section{Enzyme activities in rhizosphere soil}

The variations in enzymatic activities in the rhizosphere soil are shown in Table 2. Urease exhibited the highest activity in the second cropping. After that, the urease activity declined gradually until the fourth cropping. In contrast, the urease activity showed a gradual increase in the control throughout the cropping. Except or the third cropping, differences $(p<0.05)$ were detected in the urease activity between continuous cropping and control. The variation in soil invertase activity was similar to that of urease in the rhizosphere soil. Differently from soil urease, there were differences $(p<0.05)$ in invertase activity in each continuous cropping compared to the control. In contrast to the urease and invertase variation in the rhizosphere soil, the phosphatase activity showed an increase from the first to the third cropping and declined slightly in the fourth cropping. However, the phosphatase activity decreased gradually in the control from the first to the fourth cropping.

\section{Principal component analysis}

The PCA showed that the first principal component (PC1) explained $81 \%$ of the total variance while the second principal component (PC2) explained $12 \%$ of the total variance (Figure 3). The PCA analysis indicated a distinct separation between continuous cropping of banana and controls in soil microbiological and biochemical parameters.

Table 1 - Effects of continuous cropping of banana on MBC and MBN in rhizosphere soil.

\begin{tabular}{lcll}
\hline Cropping times & Treatments & \multicolumn{1}{c}{ MBC } & \multicolumn{1}{c}{ MBN } \\
\cline { 2 - 4 } First cropping & & \multicolumn{1}{c}{$\mathrm{mg} \mathrm{kg}^{-1}$} \\
& Control & $139.70 \pm 4.76 \mathrm{~b}$ & $26.43 \pm 1.74 \mathrm{~b}$ \\
Second cropping & Test & $220.15 \pm 4.33 \mathrm{a}$ & $64.18 \pm 10.58 \mathrm{a}$ \\
& Control & $165.00 \pm 3.78 \mathrm{~b}$ & $32.17 \pm 2.43 \mathrm{~b}$ \\
& Test & $329.05 \pm 33.37 \mathrm{a}$ & $66.62 \pm 4.90 \mathrm{a}$ \\
Third cropping & Control & $167.96 \pm 3.70 \mathrm{a}$ & $33.25 \pm 3.15 \mathrm{~b}$ \\
& Test & $194.39 \pm 15.92 \mathrm{a}$ & $52.43 \pm 6.46 \mathrm{a}$ \\
Fourth cropping & Control & $176.30 \pm 3.40 \mathrm{a}$ & $34.59 \pm 2.51 \mathrm{a}$ \\
& Test & $171.00 \pm 35.89 \mathrm{a}$ & $31.76 \pm 7.84 \mathrm{a}$
\end{tabular}

$\overline{\mathrm{MBC}}=$ soil microbial biomass carbon; $\mathrm{MBN}=$ soil microbial biomass nitrogen; Means followed by the different letters in the column within the same cropping times are significantly different at $p<0.05$ (LSD test).

\section{Correlation between bacterial16S rRNA copy, microbial biomass and enzyme activities}

The correlation analysis showed that bacterial $16 \mathrm{~S}$ rRNA copy was positively correlated with MBN $(\mathrm{r}=$ $0.999, p<0.01)$ and urease $(r=0.976, p<0.05)$ activities (Table 3). A positive correlation was also found between MBN and urease activity $(r=0.980, p<0.05)$.

There were no correlations between bacterial $16 \mathrm{~S}$ rRNA copy and invertase, and phosphatase activities.

\section{Discussion}

Agricultural management practices can affect activity of soil microorganisms (Bonilla et al., 2012; Zhang et al., 2012). In this study, a decreasing trend in soil bacterial community abundance and diversity was observed after continuous cropping of banana. Similar trend has been documented in responses in the rhizosphere soil bacterial community abundance to continuous cropping

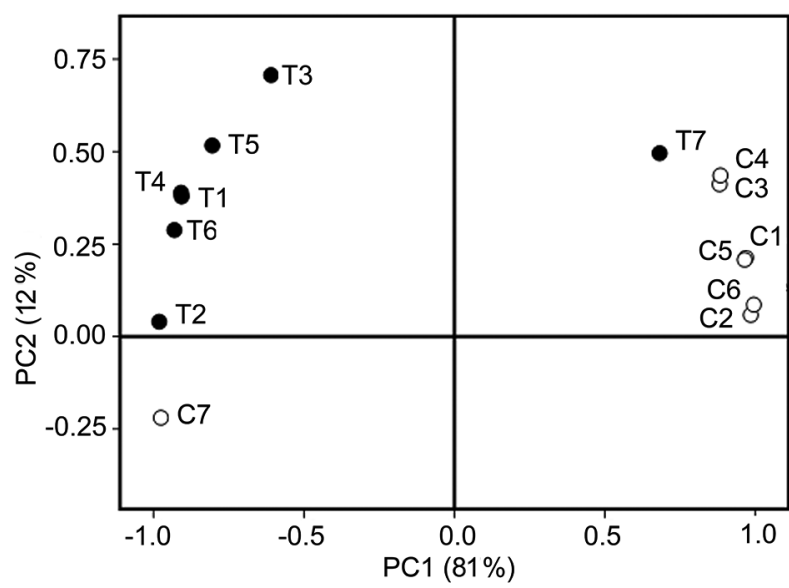

Figure 3 - Principal component analyses (PCA) results extracted from soil biochemical parameters after continuous cropping. Empty circles = controls; filled circles $=$ treatments. $\mathrm{C} 1$ and $\mathrm{T} 1=$ bacteria16S rRNA copy; C2 and T2 = bacterial diversity; C3 and $\mathrm{T} 3$ = microbial biomass carbon (MBC); 44 and $\mathrm{T} 4=$ microbial biomass nitrogen (MBN); $\mathrm{C} 5$ and $\mathrm{T} 5=$ urease activity; $\mathrm{C} 6$ and $\mathrm{T} 6$ $=$ invertase activity; $\mathrm{C} 7$ and $\mathrm{T} 7=$ phosphatase activity.

Table 2 - Soil enzyme activities in the rhizosphere of the continuous cropping of banana.

\begin{tabular}{lcccc}
\hline Cropping times & Treatments & Urease activity & Invertase activity & Phosphatase activity \\
\hline \multirow{3}{*}{ First cropping } & & NH4-N mg g-1 soil $24 \mathrm{~h}^{-1}$ & glucose $\mathrm{mg} \mathrm{g}^{-1}$ soil $24 \mathrm{~h}^{-1}$ & PNP mg g-1 soil $24 \mathrm{~h}^{-1}$ \\
& Control & $2.19 \pm 0.01 \mathrm{~b}$ & $1.80 \pm 0.04 \mathrm{~b}$ & $0.71 \pm 0.02 \mathrm{a}$ \\
Second cropping & Test & $2.49 \pm 0.05 \mathrm{a}$ & $2.21 \pm 0.01 \mathrm{a}$ & $0.61 \pm 0.01 \mathrm{~b}$ \\
& Control & $2.33 \pm 0.02 \mathrm{~b}$ & $1.92 \pm 0.04 \mathrm{~b}$ & $0.65 \pm 0.01 \mathrm{a}$ \\
Third cropping & Test & $2.57 \pm 0.03 \mathrm{a}$ & $2.27 \pm 0.03 \mathrm{a}$ & $0.66 \pm 0.03 \mathrm{a}$ \\
& Control & $2.40 \pm 0.01 \mathrm{a}$ & $2.12 \pm 0.05 \mathrm{a}$ & $0.60 \pm 0.03 \mathrm{~b}$ \\
Fourth cropping & Test & $2.44 \pm 0.03 \mathrm{a}$ & $1.97 \pm 0.03 \mathrm{~b}$ & $0.74 \pm 0.04 \mathrm{a}$ \\
& Control & $2.48 \pm 0.02 \mathrm{a}$ & $2.18 \pm 0.02 \mathrm{a}$ & $0.58 \pm 0.01 \mathrm{~b}$ \\
\hline
\end{tabular}

Means followed by the different letters in the column within the same cropping times are significantly different at $p<0.05$ (LSD test). 
Table 3 - Correlation coefficients between bacterial16S rRNA copy, MBC (soil microbial biomass carbon), MBN (soil microbial biomass nitrogen), and enzyme activities.

\begin{tabular}{|c|c|c|c|c|c|c|}
\hline & 16S rRNA copy & $\mathrm{MBC}$ & MBN & Urease & Invertase & Phosphatase \\
\hline 16S rRNA copy & 1.000 & & & & & \\
\hline $\mathrm{MBC}$ & 0.774 & 1.000 & & & & \\
\hline MBN & $0.999^{A}$ & 0.754 & 1.000 & & & \\
\hline Urease & $0.976^{a}$ & 0.751 & $0.980^{a}$ & 1.000 & & \\
\hline Invertase & 0.923 & 0.852 & 0.911 & 0.832 & 1.000 & \\
\hline Phosphatase & -0.346 & -0.258 & -0.331 & -0.136 & -0.613 & 1.000 \\
\hline
\end{tabular}

${ }^{\mathrm{a} C}$ Correlation is significant at the 0.05 level (2-tailed); ${ }^{A}$ Correlation is significant at the 0.01 level (2-tailed).

of cucumber (Zhou et al., 2014). Plant produces and releases a broad range of chemicals and metabolites. These compounds are an important factor to influence soil microorganisms (Guo et al., 2011; Ushio et al., 2013). There are differences in use of these compositions, and thus, different community structures and populations of rhizosphere soil microorganisms were formed. With the increase of continuous cropping, the effect of speciesspecific inhibition or stimulation of soil microorganisms were continued.

Microbial biomass is considered a sensitive early indicator of changes in soil conditions. In this experiment, a decreased microbial biomass was also observed from the second to the fourth cropping. The decrease in microbial biomass is probably closely associated with changes in the soil microbial community caused by continuous cropping of banana. The negative impacts of continuous cropping on microbial biomass have also been reported in other studies. For example, Allen et al. (2008) reported that soil microbial biomass in continuous cropping of cotton was lower than that in a perennial grass pasture. Nayyar et al. (2009) also found a lower microbial biomass in continuous-pea than that in a pea-wheat rotation.

Soil enzyme activity can effectively indicate soil biological activity and nutrient supply capacity, which can reflect soil ecosystem stability and soil health (Bastida et al., 2008; Stark et al., 2008). In this study, soil urease and invertase activities showed a decreasing tendency under continuous cropping of banana. Certain soil enzymes are primarily produced by specific soil microorganisms. The change in soil enzyme activities might be attributed to the shift in the microbial community composition and quantity. Several studies have demonstrated the correlations between soil enzymes and specific microbial groups. Acosta-Martínez et al. (2010) found positive correlations between some bacteria (i.e., Proteobacteria, Firmicutes and Verrucomicrobiae) and alkaline phosphatase activity in an integrated cropping livestock system. In another study, fungi and Gram-positive bacteria had strong correlations with $\beta$-glucosidase activity (Vallejo et al., 2012). On the other hand, an increase in soil phosphatase activity was observed in this experiment. It is considered that phosphatases are inducible enzymes. Previous study has shown that phosphatase activities are negatively correlated with P availability (Gil-Sotres et al., 2005).
In the present study, the soil bacterial16S rRNA copy, microbial biomass and soil urease and invertase activities exhibited increasing trends in the second cropping and then showed decreasing tendency until the fourth cropping. In contrast, there were increasing trends in soil bacterial16S rRNA copy, microbial biomass and soil urease and invertase activities in controls from the first to the fourth cropping. It is possible that fertilizers applied to the control soil supplied essential nutrients for the growth of soil microorganisms. Therefore, there are increasing trends in them.

Correlations between specific microbial groups and soil enzyme activities may provide information about how microbial community composition influences enzyme production and the specific nutrients cycling. In the present study, urease activity was positively correlated with soil bacterial16S rRNA copy. The results revealed that urease activity could serve as an indicator of the soil bacterial community, and suggested that the urease is mainly produced by soil bacteria. However, the invertase and phosphatase activities were independent of bacterial16S rRNA copy. The possible reason may be due to the shifts in microbial community composition and abundance in soils.

The results obtained in this study revealed that continuous cropping of banana has a significant effect on the soil microbiological and biochemical properties (Figure 3). Soil microorganisms and enzymes are closely correlated with soil biological processes such as nutrient cycling and organic matter decomposition. These soil biochemical and microbiological parameters could respond quickly to soil environmental changes. Consequently, soil microbial biomass and enzymes are considered sensitive indicators of soil quality and management impacts (Dick et al., 2000; Kaschuk et al., 2010). Therefore, the study on soil bacterial and biochemical properties is important to understand the effect of management practices on soil quality and develop sustainable agricultural practices.

An important cropping practice, appropriate crop rotation (e.g. banana-rice rotation) is necessary to alleviate continuous cropping obstacle of banana. In this work, the effects of continuous cropping of banana on soil microbial communities have been documented. Nevertheless, further work is required to characterize the soil microorganisms that are species-specific inhibited or stimulated, and explore the microbial functions in the continuous cropping of banana. 


\section{Acknowledgements}

This work was financially supported by the Ministry of Agriculture of China Special Fund for Agro-scientific Research in the Public Interest (N²00903049-2), National Nonprofit Institute Research Grant of CATASITBB (N ITBB110305) and The Major Technology Project of Hainan (ZDZX2013023-1).

\section{References}

Acosta-Martínez, V.; Burow, C.; Zobeck, T.M.; Allen, V. 2010. Soil microbial communities and function in alternative systems to continuous cropping of cotton. Soil Science Society of America Journal 74: 1181-1192.

Ahn, J.H.; Kim, Y.J.; Kim, T.; Song, H.G.; Kang, C.; Ka, J.O. 2009. Quantitative improvement of $16 \mathrm{~S}$ rDNA DGGE analysis for soil bacterial community using real-time PCR. Journal of Microbiological Methods 78: 216-222.

Allen, V.; Brown, C.P.; Segarra, E.; Green, C.J.; Wheeler, T.A.; Acosta-Martinez, V.; Zobeck, T.M. 2008. In search of sustainable agricultural systems for the Llano Estacado of the U.S. Southern High Plains. Agriculture, Ecosystems \& Environment 124: 3-12

Bastida, F.; Kandeler, E.; Moreno, J.L.; Ros, M.; García, C.; Hernández, T. 2008. Application of fresh and composted organic wastes modifies structure, size and activity of soil microbial community under semiarid climate. Applied Soil Ecology 40: 318-329.

Bonilla, N.; Cazorla, F.M.; Martinez-Alonso, M.; Hermoso, J.M.; Gonzalez-Fernandez, J.J.; Gaju, N.; Landa, B.B.; Vicente, A. 2012. Organic amendments and land management affect bacterial community composition, diversity and biomass in avocado crop soils. Plant and Soil 357: 215-226.

Dick, WA.; Cheng, L.; Wang, P. 2000. Soil acid and alkaline phosphatase activity as $\mathrm{pH}$ adjustment indicators. Soil Biology and Biochemistry 32: 1915-1919.

Gil-Sotres, F.; Trasar-Cepeda, C.; Leirós, M.C.; Seoane, S. 2005. Different approaches to evaluating soil quality using biochemical properties. Soil Biology and Biochemistry 37: 877887.

Guo, Z.Y.; Kong, C.H.; Wang, J.G.; Wang, Y.F. 2011. Rhizosphere isoflavones (daidzein and genistein) levels and their relation to the microbial community structure of mono-cropped soybean soil in field and controlled conditions. Soil Biology and Biochemistry 43: 2257-2264.

Hemkemeyer, M.; Christensen, B.T.; Martens, R.; Tebbe, C.C. 2015. Soil particle size fractions harbour distinct microbial communities and differ in potential for microbial mineralisation of organic pollutants. Soil Biology and Biochemistry 90: 255-265.

Joergensen, R.G.; Potthoff, M. 2005. Microbial reaction in activity, biomass, and community structure after long-term continuous mixing of a grassland soil. Soil Biology and Biochemistry 37: 1249-1258.

Kaschuk, G.; Alberton, O.; Hungria, M. 2010. Three decades of soil microbial biomass studies in Brazilian ecosystems: lessons learned about soil quality and indications for improving sustainability. Soil Biology and Biochemistry 42: 1-13.
Kizilkaya, R.; A kin, T.; Bayrakli, B.; Sa lam, M. 2004. Microbiological characteristics of soils contaminated with heavy metals. European Journal of Soil Biology 40: 95-102.

Nayyar, A.; Hamel, C.; Lafond, G.; Gossen, B.D.; Hanson, K.; Germida, J. 2009. Soil microbial quality associated with yield reduction in continuous-pea. Applied Soil Ecology 43: 115-121.

Seghers, D.; Verthé, K.; Reheul, D.; Bulcke, R.; Siciliano, S.D.; Verstraete, W.; Top, E.M. 2003. Effect of long-term herbicide applications on the bacterial community structure and function in an agricultural soil. FEMS Microbiology Ecology 46: 139-146.

Senechkin, I.V.; van Overbeeka, L.S.; van Bruggen, A.H.C. 2014. Greater Fusarium wilt suppression after complex than after simple organic amendments as affected by soil $\mathrm{pH}$, total carbon and ammonia-oxidizing bacteria. Applied Soil Ecology 73: 148-155.

Stark, C.H.; Condron, L.M.; Callaghan, M.O.; Stewart, A.; Di, H.J. 2008. Differences in soil enzyme activities, microbial community structure and short-term nitrogen mineralisation resulting from farm management history and organic matter amendments. Soil Biology and Biochemistry 40: 1352-1363.

Ushio, M.; Balser, T.C.; Kitayama, K. 2013. Effects of condensed tannins in conifer leaves on the composition and activity of the soil microbial community in a tropical montane forest. Plant and Soil 365: 157-170.

Vallejo, V.E.; Arbeli, Z.; Terán, W.; Lorenz, N.; Dick, R.P.; Roldan, F. 2012. Effect of land management and Prosopis juliflora (Sw.) DC trees on soil microbial community and enzymatic activities in intensive silvopastoral systems of Colombia. Agriculture, Ecosystems \& Environment 150: 139-148.

van Bruggen, A.H.C.; Sharma, K.; Kaku, E.; Karfopoulos, S.; Zelenev, V.V.; Blok, W.J. 2015. Soil health indicators and Fusarium wilt suppression in organically managed greenhouse soils. Applied Soil Ecology 86: 192-201.

Vance, E.D.; Brookes, P.; Jenkinson, D.S. 1987. An extraction method for measuring soil microbial biomass C. Soil Biology and Biochemistry 19: 703-707.

Wang, X.; Yuan, X.; Hou, Z.; Miao, J.; Zhu, H.; Song, C. 2009. Effect of di-(2-ethylhexyl) phthalate (DEHP) on microbial biomass $\mathrm{C}$ and enzymatic activities in soil. European Journal of Soil Biology 45: 370-376.

Zhang, B.; He, H.B.; Ding, X.L.; Zhang, X.D.; Zhang, X.P.; Yang, X.M.; Filley, T.R. 2012. Soil microbial community dynamics over a maize (Zea mays L.) growing season under conventionaland no-tillage practices in a rainfed agroecosystem. Soil \& Tillage Research 124: 153-160.

Zhou, X.; Gao, D.; Liu, J.; Qiao, P.; Zhou, X.; Lu, H.; Wu, X.; Liu, D.; Jin, X.; Wu, F. 2014. Changes in rhizosphere soil microbial communities in a continuously monocropped cucumber (Cucumis sativus L.) system. European Journal of Soil Biology 60: $1-8$.

Zhou, X.; Wu, F. 2012. Dynamics of the diversity of fungal and Fusarium communities during continuous cropping of cucumber in the greenhouse. FEMS Microbiology Ecology 80: 469-478. 